\title{
Seroprevalence of Toxoplasma gondii and associated hematological alterations in small ruminants of D.G. Khan district of Southern Punjab, Pakistan
}

[Soroprevalência de Toxoplasma gondii e alterações hematológicas associadas em pequenos ruminantes no distrito de D.G. Khan no sul de Punjab, Paquistão ]

\author{
M.H. Lashari ${ }^{1}$, U. Farooq ${ }^{2}$, S. Mubeen ${ }^{3}$, W. Hassan 4 , M.F. Azhar ${ }^{5}$, S. Shahida ${ }^{6}$, M.I. Khan ${ }^{7}$,

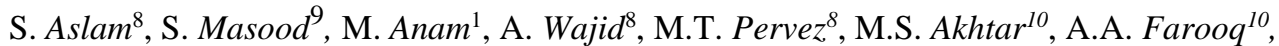 \\ S. Zafar ${ }^{11}$, M. Nawaz ${ }^{12}$, A.B. Gulshan ${ }^{13}$ \\ ${ }^{1}$ Department of Zoology, The Islamia University of Bahawalpur - Bahawalpur Pakistan \\ ${ }^{2}$ University College of Veterinary and Animal Sciences,The Islamia University of Bahawalpur -Bahawalpur, Pakistan \\ ${ }^{3}$ Sub-Campus Toba-Tek Singh, University of Agriculture - Faisalabad Pakistan \\ ${ }^{4}$ Department of Chemistry, The Women University of Multan, Multan 60000, Pakistan \\ ${ }^{5}$ Department of Forestry and Range Management Bahauddin Zakariya University, Multan, Pakistan \\ ${ }^{6}$ Department of Chemistry, University of Poonch, Rawalakot, Azad Jammu \& Kashmir, Pakistan \\ ${ }^{7}$ School of Energy and Power Engineering, Xi'an Jiaotong University, 28 West Xianning Road, Xi'an 710049, Shaanxi, PR. China \\ ${ }^{8}$ Virtual University of Pakistan - Jinnah - Defense Road, Lahore, Pakistan \\ ${ }^{9}$ Institute of Pure \& Applied Biology - Bahauddin Zakariya University - Multan, Pakistan \\ ${ }^{10}$ Faculty of Veterinary Sciences - Bahauddin Zakariya University - Multan, Pakistan \\ ${ }^{11}$ Department of Chemistry, The Government Sadiq College Women University, Bahawalpur 63000, Pakistan \\ ${ }^{12}$ Department of Environmental Science - Bahauddin Zakariya University - Multan, Pakistan \\ ${ }^{13}$ Department of Botany, Ghazi University, D. G. Khan
}

\begin{abstract}
The present study was carried out to evaluate the prevalence and hematological effects of Toxoplasma gondii in sheep and goat in district Dera Ghazi Khan. Blood samples $(n=204)$ were collected comprise goats $(n=101)$ and sheep $(n=103)$ alongwith age, gender and breeds of animals. Samples were collected randomly from 25 flocks of 7 different union council Viz. Vehova, Tibbi Qaisrani, Lakhani, Kohar, Tuman Qaisrani, Nutkani and Kot Qaisrani of Tehsil Taunsa Sharif at least 4 animals from each flock. All ruminants divide into three groups based on age, breed and gender. The prevalence was detected through two different kits Viz. LAT and ELISA kit. The overall prevalence suspected in goats through LAT and ELISA kit was (35.64\%), (32.67\%) and in sheep was $(25.24 \%),(23.30 \%)$ respectively. The Toxoplasma gondii had a significant effect on goats in age groups and non-significant all other groups of goats and sheep. Toxoplasma gondii had a significant effect on all hematological parameters like Hemoglobin, total leukocyte cells, granulocytes, lymphocytes, platelets, and red blood cells, except monocytes. In conclusion of the current study, toxoplasmosis is prevalent among ruminants, reveals the possibility of transmission to humans on the use of host animals as protein source.
\end{abstract}

Keywords: ruminants, toxoplasmosis, prevalence, LAT, ELISA, hematology

\section{RESUMO}

O objetivo do presente estudo foi avaliar a prevalência e efeitos hematológicos de Toxoplasma gondii em ovelhas e cabras no distrito Dera Ghazi Khan. Amostras de sangue $(n=204)$ foram coletadas para incluir cabras $(n=101) e$ ovelhas (n=103), além de idade, gênero e raça dos animais. Amostras foram coletadas aleatoriamente de 25 rebanhos de 7 conselhos sindicais: Vehova, Tibbi Qaisrani, Lakhani, Kohar, Tuman Qaisrani, Nutkani e Kot Qaisrani of Tehsil Taunsa Sharif com pelo menos 4 animais em cada rebanho. Todos os ruminantes foram divididos em três grupos baseados em idade, raça e gênero. A prevalência foi detectada usando dois kits, LAT e ELISA. A prevalência total suspeita em cabras através dos kits LAT e ELISA foi (35.64\%), (32.67\%) e em ovelhas foi (25.24\%), (23.30\%) respectivamente. $O$ Toxoplasma gondii teve efeito significativo em cabras em grupos de idade e não significativo em todos os outros grupos de cabras e ovelhas. Toxoplasma gondii teve efeito significativo em todos os parâmetros hematológicos como hemoglobina, células totais de leucócitos, granulócitos, linfócitos, plaquetas e glóbulos vermelhos, exceto monócitos. O presente estudo conclui que toxoplasmose é prevalente entre ruminantes, e revela a possibilidade de transmissão para humanos com o uso de animais hospedeiros como fonte de proteína.

Palavras-chave: ruminantes, toxoplasmose, prevalência, LAT, ELISA, hematologia

Recebido em 21 de setembro de 2019

Aceito em 17 de dezembro de 2019

E-mail: mushtaqlashary@gmail.com 


\section{INTRODUCTION}

Toxoplasma gondii is a well-recognized global parasite which is responsible for infestations to endothermic animals (Dubey et al., 2010). Domestic and wild cats are their definitive hosts while birds and mammals are intermediate hosts (Dubey et al., 2006). It has been estimated that $T$. gondii infection is at an average rate of 1 and $99 \%$ in animals (Andreoletti, et al., 2007). Most of the infections in small ruminants are symptomless. Small ruminants especially goat and sheep are susceptible to different parasitic diseases including toxoplasmosis that causes a range of reproductive problems such as prenatal and postnatal mortality, stillbirths or abortions leading to the economic losses and threats to human health via a zoonotic transmission (Gebremedhin et al., 2014).

Toxoplasmosis is harmful both in terms of economy and health for the country and its people. These infections have become a serious universal threat to livestock (Lashari and Tasawar, 2010). Small ruminants are a good source of meat. Humans can become infected with $T$. gondii by ingesting tissue cysts from infected animal meat, or oocysts from contaminated food or water (Elmore et al., 2010). As toxoplasmosis is considered a food born disease, therefore, to decrease the risk factors of infection travelers educate on the prevention of infection in areas with the widespread of infection (Sepúlveda et al., 2014). Risk can be estimated by understanding the serological tests for reactivation and contamination and we can identify the suitable preventive and prophylactic measures such as dietetic, therapeutic, biological, hygienic and clinical records as clinical context (Villard et al., 2016).

Moreover, sheep and goat are important sources of $T$. gondii infection in humans. Humans get the infection by ingesting raw meat having tissue cysts (Garcia et al., 1993). Higher prevalence of T. gondii is recorded in different food animals including goat, sheep, and cattle worldwide. In small ruminants the prevalence was recorded in goat $(36 \%, 62 \%, 34.5 \%, 29.13 \%)$ and sheep $(37 \%, 26 \%, 40.2 \%, 27.31 \%)$ in Africa, Egypt, Tunisia and Pakistan. Measures to control toxoplasmosis should be taken worldwide to prevent infection both from an economic and disease point of view (Kijlstra et al., 2008).
The outside souk sectors are typical in the D. G. Khan districts of southern Punjab, Pakistan and make a potential cause of pathogen pollution as the stray felines are normally found around the shops. Being a characteristic repository of $T$. gondii, they include a huge number of oocysts of the parasite through their excreta in only two or three weeks after getting the infection (Dabritz et al., 2007). The present study was conducted to investigate the prevalence of toxoplasmosis in sheep and goats concerning the breed, age, and gender with the help of LAT and ELISA kits. This is a preliminary study in this region. Therefore, raising people's awareness regarding this parasite and further studies are needed to explore the effects of the disease on livestock.

\section{MATERIAL AND METHODS}

The present investigation was conducted in Tehsil Tasunsa Sharif, district D. G. Khan, situated in the South-West of the Punjab province, Pakistan. The D.G. Khan district covers a territory of $8493 \mathrm{~km}^{2}$. The district is a stretched on a narrow strip with an extension of $317 \mathrm{~km}$, sloping steadily from the hills, form its western periphery to the River Indus on the east.

Twenty-five flocks of small ruminants (sheep and goats) selected from 7 union councils (UC) of Tehsil Taunsa Sharif, being Vehova, Tibbi Qaisrani, Nutkani, Lakhnai, Litra, Tuman Qaisrani, and Kot Qaisrani. Four animals were randomly selected from each flock for the study, and the total number of sheep was $n=103$ and goats was $n=101$.

Blood samples $(3-5 \mathrm{~mL})$ were collected from the jugular vein of ruminants $(n=204)$ as per the recommended protocol. Blood samples were stored as two aliquots: without anticoagulant for serum collection and with anticoagulant $(0.5 \mathrm{M}$ EDTA) for hematological analysis. The required data regarding age and the gender of each animal was collected at the time of sampling. Serum was separated immediately in eppendorf (serum cup) and stored at $4{ }^{\circ} \mathrm{C}$ and blood with anticoagulant was referred to the Al-Huda Clinical Laboratory of Multan, Pakistan for hematological administration.

The commercial Latex agglutination kit from the Atlas medical company was used to detect specific antibodies in the serum of hosts. For the 
test, samples and reagents were brought to room temperature. The assay was performed according to the producer's instructions.

The test procedure was carried out according to the method described by Lind et al. (1997). ELISA was performed using CALBOTECH Toxoplasma IgG ELISA kit and was used according to the manufacturer's instructions. In this analysis, the diluted patient serum sample was added to wells coated with purified antigens. If IgM antibody is present it binds to the antigen. All unbound antibodies were washed away and enzyme conjugate was added which bind to antibody- antigen complex. Excess enzyme conjugate was washed away and the substrate was added. The plate was allowed to incubate, and the color was developed. The development of color was stopped by adding stop solution and was measured at $450 \mathrm{~nm}$ with a microplate reader (Gamble et al., 2005).

For hematology analysis, vitalab flexor E automatic analyzer (Netherland) was used. The values of different hematological parameters such as RBCs, white blood cells, hemoglobin level, were determined. The prevalence is compared by using Chi-square through Minitab version 13 and all other parameters including, RBCs, platelets, TLC, hemoglobin infected and non-infected compared by using independence t-test through SPSS.

\section{RESULTS}

The results of the present study revealed that the overall prevalence of $T$. gondii in goats and sheep was $35.64 \%, 25.24 \%$ respectively through latex agglutination test (LAT) (Table 1). But according to Enzymes Linked Immunosorbent Assay (ELISA) test, the prevalence of T. gondii in goats and sheep is $32.67 \%$ and $23.07 \%$ respectively (Table 2). All selected ruminants divided into three age groups shows non-significant higher prevalence in all adult groups than younger. In the present study, a higher non-significant prevalence rate is recorded for gender in males than in females (Table 1, 2). According to ELISA, breed wise non-significant higher prevalence is shown in the kachi breed of sheep and goat teddy breed shows significantly higher prevalence (Table 1). While according to LAT in sheep, Lohi and goat Teddy breed show non-significantly higher prevalence (Table 2). The Mean \pm SEM values following hematological parameters Hemoglobin
(Hb), Total number of leucocytes (TLC), Granulocytes, Lymphocytes, Platelets and Red blood cells (RBCs) were significantly different infected hosts (Table 3).

\section{DISCUSSION}

The results of the present study revealed that the overall prevalence of $T$. gondii in goats and sheep was $35.64 \%, 25.24 \%, 32.67 \%$, and $23.07 \%$ respectively through latex agglutination test (LAT), Enzymes Linked Immunosorbent Assay (ELISA) (Table 1). The LAT was used to detect the toxoplasmosis because it is an informal, easy, inexpensive and simple method. The findings of LAT were examined by ELISA to increase diagnosis accuracy due to more specificity and accuracy of this test. According to both tests, the prevalence of $T$. gondii is higher in goats when compared to sheep.

A similar result for the prevalence of $T$. gondii in sheep was reported in Morocco at $27.6 \%$ (Sawadogo et al., 2005). Higher prevalence than the current study was recorded in Debre Birhan, Ethiopia, and Brazil and was 34\%, 32\%, 31.59\%, and $29.44 \%$ respectively (Tilaye, and Getachew, 2002, Clementino et al., 2007, Pinheiro 2009, Gebremedhin et al., 2013). While the lower prevalence was recorded in Pakistan, Nigeria and Northeastern China were $11.1 \%, 6.7 \%$ and $3.0 \%$ respectively (Ramzan et al., 2009, Kamani, et al., 2010, Wang et al., 2011).

Similar prevalence of $T$. gondii in goat was reported in Ethiopia at 35\% (Bekele and Kasali 1989). Higher prevalence than the current study was recorded in Egypt at $44.3 \%$ (Shaapan et al., 2010). While the lower prevalence was recorded in Thailand, Ethiopia, and Central Ethiopia were $27.9 \%, 25.9 \%, 15.48 \%$ and $11.6 \%$ respectively (Jittapalapong et al., 2005, Negash et al., 2004, Gebremedhin et al., 2014).

The overall higher prevalence was recorded in goat when compared to sheep. The similar higher prevalence in $\mathrm{g}$ was reported in Pakistan (goat 42.8\%, sheep 26.24\%) and Egypt (goat 62\%, sheep 26\%) (Ahmed et al., 2016, Al-Kappany 2018). Contrasting results also reported in Ethiopia (goat 27.6\%, sheep 33.7\%), Africa (goat $22.9 \%, 26 \%)$ and Tunisia $(34.5 \%, 40.2 \%)$ (Tilahunn et al., 2018, Tonouhewa et al., 2017, Lahmar et al., 2015). 
Table 1. Prevalence of Toxoplasma gondii in sheep and goat by LAT on basis of age, gender and breed

\begin{tabular}{|c|c|c|c|c|}
\hline Parameters & Total No. of Hosts & No. of Infected Hosts & Prevalence $\%$ & Predictive Value \\
\hline \multicolumn{5}{|c|}{ The overall prevalence in sheep by LAT } \\
\hline Prevalence & 103 & 26 & 25.24 & \\
\hline \multicolumn{5}{|c|}{ Age wise prevalence } \\
\hline $8-19$ & 34 & 7 & 20.58 & \multirow{3}{*}{$\mathrm{P}=0.01$} \\
\hline $20-31$ & 42 & 7 & 16.66 & \\
\hline $32-42$ & 27 & 12 & 44.44 & \\
\hline \multicolumn{5}{|c|}{ Gender wise prevalence } \\
\hline Female & 88 & 21 & 23.86 & \multirow{2}{*}{$\mathrm{P}=0.05$} \\
\hline Male & 15 & 5 & 33.33 & \\
\hline \multicolumn{5}{|c|}{ Breed wise prevalence } \\
\hline Kachi & 51 & 12 & 23.52 & \multirow{2}{*}{$\mathrm{P}=0.7$} \\
\hline Lohi & 52 & 14 & 26.92 & \\
\hline \multicolumn{5}{|c|}{ The overall prevalence in goat by LAT } \\
\hline Prevalence & 101 & 36 & 35.64 & \\
\hline \multicolumn{5}{|c|}{ Age wise prevalence } \\
\hline $8-21$ & 29 & 05 & 17.24 & \multirow{3}{*}{$\mathrm{P}=0.09$} \\
\hline $22-35$ & 42 & 14 & 33.33 & \\
\hline $36-49$ & 30 & 17 & 56.66 & \\
\hline \multicolumn{5}{|c|}{ Gender wise prevalence } \\
\hline Female & 93 & 33 & 35.48 & \multirow{2}{*}{$\mathrm{P}=0.9$} \\
\hline Male & 8 & 3 & 37.5 & \\
\hline \multicolumn{5}{|c|}{ Breed wise prevalence } \\
\hline Teddy & 27 & 11 & 40.74 & \multirow{3}{*}{$\mathrm{P}=0.6$} \\
\hline $\mathrm{CB}$ & 44 & 17 & 38.63 & \\
\hline Nachi & 30 & 8 & 26.66 & \\
\hline
\end{tabular}

Table 2. Prevalence of $T$. gondii in sheep and goat by ELISA based on age, gender and breeds

\begin{tabular}{|c|c|c|c|c|}
\hline Parameters & Total No. of Host & No. of Infected Host & Prevalence $\%$ & Predictive Value \\
\hline \multicolumn{5}{|c|}{ The overall prevalence in sheep by ELISA } \\
\hline Prevalence & 103 & 24 & 23.30 & \\
\hline \multicolumn{5}{|c|}{ Age wise prevalence } \\
\hline $8-19$ & 34 & 5 & 14.70 & \multirow{3}{*}{$\mathrm{P}=0.031$} \\
\hline $20-31$ & 41 & 9 & 21.95 & \\
\hline $32-42$ & 28 & 10 & 35.71 & \\
\hline \multicolumn{5}{|c|}{ Gender wise prevalence } \\
\hline Female & 88 & 19 & 21.59 & \multirow{2}{*}{$\mathrm{P}=0.04$} \\
\hline Male & 15 & 5 & 33.33 & \\
\hline \multicolumn{5}{|c|}{ Breed wise prevalence } \\
\hline Kachi & 51 & 12 & 23.52 & \multirow{2}{*}{$\mathrm{P}=0.9$} \\
\hline Lohi & 52 & 12 & 23.07 & \\
\hline \multicolumn{5}{|c|}{ The overall prevalence in goat by ELISA } \\
\hline Prevalence & 101 & 33 & 32.67 & \\
\hline \multicolumn{5}{|c|}{ Age wise prevalence } \\
\hline $8-21$ & 29 & 04 & 13.79 & \multirow{3}{*}{$\mathrm{P}=0.04$} \\
\hline $22-35$ & 42 & 12 & 28.57 & \\
\hline $36-49$ & 30 & 17 & 56.66 & \\
\hline \multicolumn{5}{|c|}{ Gender wise prevalence } \\
\hline Female & 93 & 31 & 33.33 & \multirow{2}{*}{$\mathrm{P}=0.7$} \\
\hline Male & 8 & 2 & 25 & \\
\hline \multicolumn{5}{|c|}{ Breed wise prevalence } \\
\hline Teddy & 27 & 11 & 40.74 & \multirow{3}{*}{$\mathrm{P}=0.5$} \\
\hline $\mathrm{CB}$ & 44 & 15 & 34.09 & \\
\hline Nachi & 30 & 7 & 23.33 & \\
\hline
\end{tabular}


Table 3. Mean \pm SEM values of hematological parameters of Toxoplasma gondii in infected and noninfected sheep and goat

\begin{tabular}{lcccc}
\hline \multicolumn{1}{c}{ Species } & \multicolumn{2}{c}{ Sheep } & \multicolumn{2}{c}{ Goats } \\
\hline \multicolumn{1}{c}{ Parameters } & $\begin{array}{c}\text { Infected } \\
(\text { Mean } \pm \text { SEM) }\end{array}$ & $\begin{array}{c}\text { Non infected } \\
(\text { Mean } \pm \text { SEM) }\end{array}$ & $\begin{array}{c}\text { Infected } \\
(\text { Mean } \pm \text { SEM) }\end{array}$ & $\begin{array}{c}\text { Non infected } \\
(\text { Mean } \pm \text { SEM) }\end{array}$ \\
\hline RBCs & $12.25 \pm .354$ & $12.42 \pm .220$ & $13.76 \pm .441$ & $13.51 \pm .559^{*}$ \\
$\mathrm{Hb}$ & $7.34 \pm .222^{*}$ & $9.37 \pm .170^{*}$ & $9.98 \pm .258^{*}$ & $9.85 \pm .425^{*}$ \\
Platelets & $896.65 \pm 29.44^{*}$ & $916.56 \pm 48.66^{*}$ & $516.99 \pm 15.72^{*}$ & $516.89 \pm 17.923^{*}$ \\
TLC & $8.21 \pm .248^{*}$ & $7.58 \pm .215^{*}$ & $10.44 \pm 1.450^{*}$ & $10.37 \pm .640^{*}$ \\
Granulocytes & $4.44 \pm .176^{*}$ & $4.14 \pm .138^{*}$ & $5.68 \pm .849^{*}$ & $5.68 \pm .372^{*}$ \\
Lymphocytes & $3.19 \pm .125^{*}$ & $2.85 \pm .0893^{*}$ & $3.98 \pm .524^{*}$ & $3.96 \pm .262^{*}$ \\
Monocytes & $2.32 \pm 1.629$ & $0.55 \pm .027$ & $0.75 \pm .096$ & $0.75 \pm .089$ \\
\hline
\end{tabular}

*The data in table labeled with asterisks indicate a significant effect $(\mathrm{P} \leq 0.05)$

Older animals are more susceptible to get an infection than younger ones. According to the present study the prevalence of $T$. gondii was higher in the older group of small ruminants than younger in both LAT and ELISA tests (Table 1, 2). Similar findings are given in previously reported literature by Clementino et al., 2007 and Figueiredo et al., 2001. Age is considered a major factor to make the animals more susceptible to T.gondii (Dumetre et al., 2006). In contrast to current study, higher prevalence was recorded in younger animal groups when compared to older (Pawelec et al., 2002; Lashari and Tasawar, 2010) which may be due to less immunity. According to the results of the current study, higher prevalence was recorded in older ruminant groups which may be due to having a wide range of feeding area and have greater chance to encounter $T$. gondii oocyte contaminated food or water.

In the present study gender wise non- significant higher prevalence was record in males as opposed to females. However, the higher prevalence in females was also record in goat samples analyzed with ELISA (Table 1, 2). Various studies reported similar results in which males are more prevalent to T. gondii than females (Silva et al., 2003, Lashari and Tasawar, 2010). While contrasting to the current study results also reported by Ntafis et al. 2007; Acici et al. 2008, Ramzan et al., 2009.

Breed showed different rate of parasite prevalence. Similar results to the current study with higher prevalence in the Kacchi breed of sheep reported by Lashari and Tasawar (2010). The Teddy breed of goat is more susceptible to $T$. gondii than other breeds. This is all due to resistance or immunity of breed because different breeds have different resistance to parasitic infections. Some breeds are more resistant than others.

Species wise $T$. gondii has a significant effect on all hematological parameters except monocytes given in Table 3. Similar findings were reported by Qamar and Maqbool, 2012. Similar results to our study where significantly decreased levels of $\mathrm{Hb}$ and $\mathrm{RBCs}$ in host when $T$. gondii attacked them while monocyte decreased non-significantly in the current study seem to be an important defense strategy devised by the parasites, reported by Clark et al. (1962). Change in hematological parameters decreasing the level of RBC indicates the severity of infection in the host.

\section{CONCLUSION}

In conclusion, there was a higher prevalence of $T$. gondii in goats than in sheep. A higher prevalence was also recorded in adults and males. Older animals have more chance to encounter oocytes spread into the environment. While the males were more susceptible to get an infection than female, some, hematological parameters may alter, which helps to estimate the level of infection. This is a preliminary study of such type having little available literature. In Pakistan, small ruminants such as sheep and goat are used as the best source of meat. They are the intermediate host of $T$. gondii which resides in host tissues in form of tissue cysts of hosts. Small ruminant play an important role in the transmission of this disease to other animals and should be further explored with a large sample and population. 


\section{FUTURE RECOMMENDATIONS}

There is need to formulate some strategies which eradicate the infestation $T$. gondii and management of such practices should be implemented to reduce the prevalence rate of $T$. gondii in small ruminants in the rural areas of the D.G. Khan district.

\section{REFERENCES}

AHMED, H.; MALIK, A.; ARSHAD, M. et al. Seroprevalence and spatial distribution of toxoplasmosis in sheep and goats in NorthEastern Region of Pakistan. Korean J. Parasitol., v.54p.439-445, 2016.

AL-KAPPANY, Y.M.; ABBAS, I.E.; DEVLEESSCHAUWER, B. et al. Seroprevalence of anti-Toxoplasma gondii antibodies in Egyptian sheep and goats. BMC Vet. Res. v.14, p.120-1214, 2018.

ANDREOLETTI, O.; BUDKA, H.; BUNCIC, S. et al. Scientific opinion of the panel on biological hazards on a request from EFSA on surveillance and monitoring of Toxoplasma in humans, foods and animals. Eur. Food Saf. Authority J., v.583 p.1-64, 2007.

BEKELE, T.; KASALI, O.B. Toxoplasmosis in sheep, goats and cattle in central Ethiopia. Vet. Res. Commun., v.13, p.371-375, 1989.

CLARK, C.H.; KIESEL, G.K.; GOBY, C.H. et al. Measurements of blood loss caused by Haemonchus contortus infection in 177 sheep. Am. J. Vet. Res., v.23, p.977-980,1962.

CLEMENTINO, M.M.; SOUZA, M.F.; NETO, V.A. Seroprevalence and Toxoplasma gondii-IgG avidity in sheep from Lajes, Brazil. Vet. Parasitol., v.146, p.199-203, 2007.

DABRITZ, H.A.; MILLER, M.A.; ATWILL, E.R. et al. Detection of Toxoplasma gondii-like oocysts in cat feces and estimates of the environmental oocyst burden. J. Am. Vet. Med. Assoc., v.231, p.1676-1684, 2007.

DUBEY, J.P.; FELIX, T.A.; KWOK, O.C.H. Serological and parasitological prevalence of Toxoplasma gondii in wild birds from Colorado. J. Parasitol., v.96, p.937-940, 2010.
DUBEY, J.P.; SUNDAR, N.; PINEDA, N. et al. Biologic and genetic characteristics of Toxoplasma gondii isolates in free-range chickens from Nicaragua, Central America. Vet. Parasitol., v.142 p.47-53, 2006.

DUMÈTRE, A.; AJZENBERG, D.; ROZETTE, L. et al. Toxoplasma gondii infection in sheep from Haute-Vienne, France: seroprevalence and isolate genotyping by microsatellite analysis. Vet. Parasitol., v.142, p.376-379, 2006.

ELMORE, S.A.; JONES, J.L.; CONRAD, P.A. et al. Toxoplasma gondii: epidemiology, feline clinical aspects, and prevention. Trends Parasitol., v.26, p.190-196, 2010.

FIGUEIREDO, J.F.; SILVA, D.A.; CABRAL, D.D. et al. Seroprevalence of Toxoplasma gondii infection in goats by the indirect haemagglutination, immunofluorescence and immunoenzymatic tests in the region of Uberlandia, Brazil. Mem. Inst. Oswaldo Cruz, v.96, p.687-692, 2001.

GAMBLE, H.R.; DUBEY, J.P.; LAMBILLOTTE, D.N. Comparison of a commercial ELISA with the modified agglutination test for detection of Toxoplasma infection in the domestic pig. Vet. Parasitol., v.128, p.177-181, 2005.

GARCÍA-VÁZQUEZ, Z.; ROSARIO-CRUS, R.; DIAZ-GARCIA, G. et al. Seroprevalence of Toxoplasma gondii infection in cattle, swine and goats in four Mexican states. Prev. Vet. Med., 17, p.127-132, 1993.

GEBREMEDHIN, E.Z.; ABDURAHAMAN, M.; HADUSH, T. et al. Seroprevalence and risk factors of Toxoplasma gondii infection in sheep and goats slaughtered for human consumption in Central Ethiopia. BMC Res. Notes, v.7, p.696699, 2014.

GEBREMEDHIN, E.Z.; AGONAFIR, A.; TESSEMA, T.S. et al. Seroepidemiological study of ovine toxoplasmosis in East and West Shewa Zones of Oromia regional state, Central Ethiopia. BMC Vet. Res., v.9, p.117-122, 2013.

JITTAPALAPONG, S.; SANGVARANOND, A.; PINYOPANUWAT, N. et al. Seroprevalence of Toxoplasma gondii infection in domestic goats in Satun Province, Thailand. Vet. Parasitol., v.127, p.17-22, 2005 
KAMANI, J.; MANI, A.U.; AND EGWU, G.O. Seroprevalence of Toxoplasma gondii infection in domestic sheep and goats in Borno state, Nigeria. Trop. Anim. Health Prod., v.42, p.793-797, 2010.

KIJLSTRA, A.; JONGERT, E. Control of the risk of human toxoplasmosis transmitted by meat. Int. J. Parasitol., v.38, p.1359-1370, 2008.

LAHMAR, I.; LACHKHEM, A.; SLAMA, D. et al. Prevalence of toxoplasmosis in sheep, goats and cattle in Southern Tunisia. J. Bacteriol. Parasitol., v.6, p.1-7, 2015.

LASHARI, M.H.; TASAWAR, Z. Seroprevalence of toxoplasmosis in sheep in Southern Punjab, Pakistan. Pak. Vet. J., v.30, p.91-94, 2010.

LIND, P.; HAUGEGAARD, J.; WINGSTRAND, A. et al. The time course of the specific antibody response by various ELISAs in pigs experimentally infected with Toxoplasma gondii. Vet. Parasitol., v.71, p.1-15, 1997.

NEGASH, T.; TILAHUN, G.; PATTON, S. et al. Serological survey on toxoplasmosis in sheep and goats in Nazareth, Ethiopia. Rev. Med. Vet., v.155, p.486-488, 2004.

PAWELEC, G.; BARNETT, Y.; FORSEY, R. et al. T cell and aging. Front. Biol. Sci., v.7, p.156183. 2002.

PINHEIRO, J.W.; MOTA, R.A.; DAFONSECA, O.A.A. et al. Prevalence and risk factors associated to infection by Toxoplasma gondii in ovine in the State of Alagoas, Brazil. Parasitol. Res., v.105, p.709-712, 2009

QAMAR, M.F.; MAQBOOL, A. Biochemical studies and serodiagnosis of haemonchosis in sheep and goats. J. Anim. Plant Sci., v.22, p.32$38,2012$.

RAMZAN, M.; AKHTAR, M.; MUHAMMAD, F. et al. Seroprevalence of Toxoplasma gondii in sheep and goats in Rahim Yar Khan (Punjab), Pakistan. Trop. Anim. Health Prod., v.41, p.12251229, 2009
SAWADOGO, P.; HAFID, J.; BELLETE, B. et al. Seroprevalence of $T$. gondii in sheep from Marrakech, Morocco. Vet. Parasitol., v.130, p.8992, 2005.

SEPÚLVEDA-ARIAS, J.C.; GÓMEZ-MARIN, J.E.; BOBIĆ, B. et al. Toxoplasmosis as a travel risk. Travel. Med. Infect. Dis., v.12, p.592-601, 2014.

SHAAPAN, R.M.; HASSANAM, M.A.; KHAHL, F.A.M. Modified agglutination test for serologic survey of Toxoplasma gndii infection in goats and water buffaloes in Egypt. Res. J. Parasitol., v.5, p.13-17, 2010.

SILVA, A.V.D.; CUNHA, E.L.P.; MEIRELES, L.R. et al. Sheep and goat toxoplasmosis: soroepidemiological study in two regions in the State of Pernambuco, Brazil Ciênc. Rural, v.33, p.115-119, 2003.

TILAHUN, B.; TOLOSSA, Y.H.; TILAHUN, G. et al. Seroprevalence and risk factors of Toxoplasma gondii infection among domestic ruminants in East Hararghe zone of Oromia Region, Ethiopia. Vet. Med. Int., v.2018, p.1-8, 2018.

TILAYE, D.; GETACHEW, T. Study on toxoplasmosis in sheep and goats in Debre Birhan and surrounding areas in Ethiopia. Bull. Anim. Health Prod. Afr., v.50, p.138-147, 2002.

TONOUHEWA, A.B.N.; AKPO, Y.; SESSOU, P. et al. Toxoplasma gondii infection in meat animals from Africa: Systematic review and metaanalysis of sero-epidemiological studies. Vet. World, v.10 p.194-208, 2017.

VILLARD, O.; CIMON, B.; L'OLLIVIER, C. et al. Serological diagnosis of Toxoplasma gondii infection: recommendations from the French National Reference Center for Toxoplasmosis. Diagn. Microbiol. Infect. Dis., v.84, p.22-33, 2016.

WANG, C.R.; QIU, J.H.; GAO, J.F. et al. Seroprevalence of Toxoplasma gondii infection in sheep and goats in northeastern China. Small Ruminant Res., v.97, p.130-133, 2011. 